\begin{tabular}{|l|l|l|}
\hline \multicolumn{2}{|c|}{ PublisherInfo } \\
\hline \hline PublisherName & $:$ & BioMed Central \\
\hline \hline PublisherLocation & $:$ & London \\
\hline \hline PublisherImprintName & $:$ & BioMed Central \\
\hline \hline
\end{tabular}

\title{
Everything binds everything
}

\begin{tabular}{|l|l|l||}
\hline \multicolumn{2}{|c|}{ ArticleInfo } \\
\hline \hline ArticleID & $:$ & 3849 \\
\hline \hline ArticleDOI & $:$ & $10.1186 /$ gb-spotlight-20001204-01 \\
\hline \hline ArticleCitationID & $:$ & spotlight-20001204-01 \\
\hline \hline ArticleSequenceNumber & $:$ & 286 \\
\hline \hline ArticleCategory & $:$ & Research news \\
\hline \hline ArticleFirstPage & $:$ & 1 \\
\hline \hline ArticleLastPage & $:$ & 2 \\
\hline \hline & & RegistrationDate : 2000-12-04 \\
ArticleHistory & $:$ & OnlineDate $\quad$ 2000-12-04 \\
\hline \hline ArticleCopyright & $:$ & BioMed Central Ltd2000 \\
\hline \hline ArticleGrants & $:$ & \\
\hline \hline ArticleContext & $:$ & 130591111 \\
\hline \hline
\end{tabular}


William Wells

Email:wells@biotext.com

In the December Nature Biotechnology Schwikowski et al. combine the large-scale two-hybrid analyses of Uetzet al. and Itoet al. with other published two-hybrid results to come up with a total of 2,709 interactions encompassing 2,039 different yeast proteins. The synthesis of these results yields a single large network of 2,358 interactions among 1,548 yeast proteins, with the next largest network containing only 19 proteins (Nat Biotechnol 2000, 18:1257-1261). Connections between proteins assigned to different functional groups suggests, for example, that protein folding and translocation are related, as are RNA processing and translation. The connections can also be used to determine the function of uncharacterized proteins, with multiple connections to one process strengthening the case. There are, however, only 364 yeast proteins of unknown function that have at least one partner of known function, and only 69 with two or more partners of known function. Of those 69, only 29 have two or more interacting proteins with at least one function in common. Studies of indirect connections (i.e., connections two or more steps away from the protein under study) can, however, allow more proteins to be tentatively assigned a function.

\section{References}

1. Nature Biotechnology, [http://www.nature.com/nbt/]

2. A comprehensive analysis of protein-protein interactions in Saccharomyces cerevisiae.

3. Toward a protein-protein interaction map of the budding yeast: A comprehensive system to examine two-hybrid interactions in all possible combinations between the yeast proteins.

This PDF file was created after publication. 